\title{
International cooperation for food and nutrition security: Systematization of the participatory, contextualized, and intersectoral educational practices
}

\author{
Cooperação internacional em segurança \\ alimentar e nutricional: sistematização \\ de práticas educativas participativas, \\ contextualizadas e intersetoriais
}

\author{
Luciene BURLANDY ${ }^{1}$ \\ Cecilia ROCHA² \\ Renato Sérgio MALUF ${ }^{3}$ \\ Maria Marlene Marques ÁVILA ${ }^{4}$ \\ Daniele Mendonça FERREIRA ${ }^{1}$ \\ Silvia Eliza Almeida PEREIRA ${ }^{1}$
}

\section{A B S T R A C T}

The present study systematized the experience gained with the project Construindo capacidades em segurança alimentar e nutricional no Brasil, Canadá e Angola (2004-2010, Building food and nutrition security skills in Brazil, Canada, and Angola), whose objective was to qualify actions that promote food and nutrition security in the three countries using different educational practices. The activities were organized in the following subprojects: (a) online distance learning courses; (b) workshops to train managers, government technicians, representatives of civil society organizations, and social subjects who offered to act as a link between communities; and (c) local pilot projects. The present study reports this experience. The educational practices implemented in the municipalities of Araçuaí (MG), Juazeiro (BA), and Fortaleza (CE) were analyzed based on systematized information in the project reports and activity records (texts and photographs). The analytical reference was based on the concept of food and nutrition education, guided by the fundamentals of Popular Education and Paulo Freire;

\footnotetext{
1 Universidade Federal Fluminense, Faculdade de Nutrição, Departamento de Nutrição Social. R. Mário Santos Braga, 30 , $4^{\circ}$ andar. Centro, 24020-140, Niterói, RJ, Brasil. DM FERREIRA. E-mail: <daniele_ferreira@id.uff.br>.

2 Ryerson University, Centre for Studies in Food Security. Toronto, Canada.

3 Universidade Federal Rural do Rio de Janeiro, Departamento de Desenvolvimento, Agricultura e Sociedade, Programa de Pós-Graduação. Rio de Janeiro, RJ, Brasil.

${ }^{4}$ Universidade Estadual do Ceará, Curso de Nutrição. Fortaleza, CE, Brasil.
} 
on the concept of food and nutrition security; and on the following analytical dimensions: participation, contextualization of educational practices, and intersectoriality. The results evidenced how educational practices contributed to the construction of shared concepts of food and nutrition security from an intersectoral and participatory perspective that values the peculiarities of diet in different socioeconomic and cultural contexts, and highlights daily situations and local traditions. They also expose the limits and potentialities of an experience of this magnitude, conducted from an interdisciplinarity perspective and using participatory methods.

Keywords: Education. Food and nutrition education. Food and nutrition security.

\section{RE S U M O}

O presente estudo consiste em uma sistematização da experiência do projeto Construindo capacidades em segurança alimentar e nutricional no Brasil, Canadá e Angola (2004-2010), que teve como objetivo qualificar as ações promotoras de segurança alimentar e nutricional nos três países por meio de diferentes práticas educativas. As atividades foram organizadas nos seguintes subprojetos: (a) cursos de formação à distância (online); (b) oficinas de qualificação de gestores, técnicos de governos, representantes de organizações da sociedade civil e sujeitos sociais que se dispuseram a atuar como elos entre as comunidades; (c) projetos piloto no nível local. Dessa maneira, o estudo consiste em um relato dessa experiência. Foram analisadas as práticas educativas implementadas nos municípios de Araçuaí (MG), Juazeiro (BA) e Fortaleza (CE) a partir das informações sistematizadas nos relatórios do projeto e registros de atividades (escritos e fotográficos). O referencial analítico baseou-se no conceito de educação alimentar e nutricional, pautado nos fundamentos da Educação Popular e de Paulo Freire, no conceito de segurança alimentar e nutricional e nas seguintes dimensões de análise: participação, contextualização das práticas educativas e intersetorialidade. Os resultados evidenciam como as práticas educativas contribuíram para uma construção compartilhada de concepções sobre Segurança Alimentar e Nutricional, numa perspectiva intersetorial e participativa, ao valorizarem as peculiaridades da alimentação nos diferentes contextos socioeconômicos e culturais e evidenciarem situações cotidianas e tradições locais. Apontam, também, os limites e potencialidades de uma experiência de tal amplitude e diversidade, conduzida sob a ótica da interdisciplinaridade e do trabalho participativo.

Palavras-chave: Educação. Educação alimentar e nutricional. Segurança alimentar e nutricional.

\section{NTRODUCTION}

Food and Nutrition Security (FNS) is present in the public agenda and guides the action of various national governments to a greater or smaller degree. Abroad, Brazil stands out because of the experience it gained constructing a broad, intersectoral, and participatory approach, and developing public policies organized into one nationwide FNS system (Sistema Nacional de Segurança Alimentar e Nutricional [SISAN, System, Food and Nutrition Security]) ${ }^{1}$.

The concept of FNS, formalized in the Lei Orgânica de Segurança Alimentar e Nutricional (LOSAN, Organic Law of Food and Nutrition Security), consists of permanently ensuring the human right to a healthy, accessible, quality, and adequate diet that does not compromise access to other essential needs, that is based on healthy eating practices, that respects cultural diversity, and that is socioeconomically and agroecologically sustainable?2.

The operationalization of a FNS policy involves actions developed by different sectors of the government and society that pass through the spheres of production, commercialization, access, and use of food at the family and biological levels. This broader focus presupposes articulation and integration between the food dimension (production, commercialization, and consumption) and nutrition dimension (biopsychosocial processes of nutrition and their relationship with health) ${ }^{3-6}$ of food and nutrition security.

The current nutritional status profile of the Brazilian population (characterized by obesity, micronutrient deficiencies, hunger, and malnutrition) and their dietary profile (marked by growing 
consumption of processed products and inadequate intakes of fruits and vegetables $)^{7,8}$ is strongly conditioned by the way foods are produced and commercialized in the country. Therefore, the promotion of eating practices that meet cultural, social, environmental, and health aspects requires the transformation of the food production model (transitioning to agroecological modes of production) and new forms of distribution, commercialization, and access. Recognizing that the main food and nutrition problems are deeply related to the characteristics of the current food production system (use of pesticides, loss of biodiversity, and environmental and social damages, among others) was critical for consolidating intersectoriality as a strategic principle, and even as an identity principle, of the FNS policy ${ }^{3-5}$.

Brazil has advanced in the consolidation of SISAN and during this process, the principle of intersectoriality potentially encourages dialogue between managers and professionals whose work has been historically guided by specific sectoral policies (agriculture, health, education, and social assistance, among others) and developed in a fragmented and poorly integrated fashion ${ }^{6}$. This movement also helps to redimension the more specific objectives of the health sector, including Food and Nutrition Education (FNE) actions, which historically have been constituted as a prescriptive practice, almost entirely restricted to the knowledge core of the science of nutrition, focused on the consumption and food intake dimensions and on the dissemination of information about health risks ${ }^{9,10}$. This reductionist approach is being reviewed and the implementation in 2012 of the Marco de Referência em Educação Alimentar e Nutricional Food and Nutrition Education, Reference Benchmark) contributed to the consolidation of a broader concept, guided by a dialogic, reflexive, and participatory perspective of education ${ }^{11}$.

In agreement with this reference, the shared construction of political concepts and processes between different social subjects is particularly important in the trajectory of SISAN institutionalization. The Councils and Conferences in the three levels of government, integrated by technicians and managers of different government sectors and societal organizations, are instances of social participation, with a majority from the civil society responsible for formulating the Politica Nacional de Segurança Alimentar e Nutricional (National Food and Nutrition Education Policy)2. Many actors have participated in this process with differentiated institutional vocations in the FNS field, which demands an extensive education related to the theme.

If, on the one hand, the participants of these institutional spaces are directly involved with political FNS action, on the other hand, they act in multiple ways in local processes that affect food production, commercialization, and consumption practices. They are individuals who transform the social reality, which requires them to reflect not only about the actions developed by the governments and social institutions, but also about their own practices, including eating practices, to potentiate and qualify their political action. Therefore, the FNS councils are strategic for the development of FNE actions 9 .

In addition to participating in government spaces, civil society institutions in different countries compose networks of policies that develop actions in the field of FNS ${ }^{4,6}$. In Brazil the concept of FNS was constructed by a broad, participatory process, which involved civil society organizations and social movements with different experiences inserting the theme nationwide and at the community level. These institutions deal with many issues related to food production, commercialization, and consumption; the environment; rurality; health; and gender, racial, and ethnic inequalities, among others, which favor an intersectoral perspective, also to dialogue with different relevant governmental sectors (agriculture, health, education, etc.). Some of them gained extensive experience with educational activities for different population segments ${ }^{3,6}$. 
Given the potentialities of this process, the project Construindo Capacidades em Segurança Alimentar e Nutricional (CCSAN, Building Capacity in Food and Nutrition Security) no Brasil, Canadá e Angola conducted from 2004 to 2010, aimed to promote an exchange of FNS experiences in the three countries and to potentiate the practices developed by social agents (governmental and societal). Brazil included the municipalities of Araçuai (MG), (in the Vale de Jequitinhonha, in the northern region of the state of Minas Gerais); Juazeiro (São Francisco River valley in Bahia) and Fortaleza (capital of the state of Ceará). In Canada the project was developed in Toronto, and in Angola, in the municipalities of Luanda and Huambo.

The present study systematized this experience, focusing on the educational practices developed in the Brazilian cities of Araçuaí, Juazeiro, and Fortaleza, analyzed from the perspective of FNS and FNE concepts.

\section{Conceptual references}

The educational practices developed during CCSAN were analyzed based on the concept of FNS described earlier and on the educational references that guide the concept of FNE formalized by the Marco de Referência de Educação Alimentar e Nutricional nas Políticas Públicas (Reference Framework for Food and Nutrition Education in Public Policies) ${ }^{11}$. Implemented in 2012, its objective was to promote a field of reflection and guidance of FNE practice based on critical pedagogy, identified in Educação Popular (Popular Education) by Paulo Freire, which is based on integration and dialogue $^{12}$.

Educational practice can be defined as a set of actions performed in a learning environment guided by a given pedagogical concept ${ }^{13}$. Such actions involve pedagogical techniques, which are the methodological instruments that support the learning process, such as lectures, dramatization, seminars, case studies, working group debates, and the pedagogical resources (means), which are the materials used to help the techniques (methods) to achieve the expected results, such as videos, music, illustrations, books, articles, poetry, blackboard, multimedia, etc. ${ }^{14}$.

The perspective of critical pedagogy ${ }^{15}$ values significant learning by contextualizing the content according to the individual's reality. Understanding and transforming reality require critical reflection ${ }^{16}$ and collective knowledge construction in the scope of human relations and experiences shared in a given social, cultural, and historic context. Hence, collective transformation occurs as individuals seek for concrete solutions for daily problems ${ }^{15,17}$.

This reference contributes to the consolidation of a broader FNE concept, like a field of knowledge and of continuous, permanent, transdisciplinary, intersectoral, and multidisciplinary practice that aims to promote the autonomous and voluntary practice of healthy eating habits. FNE practice should use problematizing and active educational approaches and resources that favor dialogue with individuals and population groups, considering all life stages, all stages of the food system, and the interactions and meanings that compose eating behavior ${ }^{11}$.

Food and Nutrition Education practices aim to promote individual autonomy, interdisciplinarity, and transdisciplinarity, to respect food cultures, to value food history and regional diversity, to recognize popular knowledge, and to promote local biodiversity ${ }^{18}$. This approach is in agreement with the FNS educational perspective, which also presupposes dialogic educational practices that contribute to the following principles: recognition of the subject-learner as an agent of the action that changes the social reality; social participation; greater understanding of the food system (from production to consumption); and an integrated analysis of food and nutrition dimensions of food and nutrition security $5,9,11$. 
Therefore, the concepts of FNE and FNS demand inter- and transdisciplinary focuses and new types of relationships between managers, professionals, and population that enable a participatory and integrative action planning. This in itself is a challenge to the educational practices that historically have guided our education processes since they need to be adapted to the local reality (contextualization); participatory practices that promote the sharing not only of information, but experiences and reflections about the factors that condition the FNS situation of each context; critical and integrated analysis of these conditioners and promotion of values that guide the human right to adequate and healthy food.

\section{METHODS}

This study is characterized as a systematization of experiences, which, according to Holliday ${ }^{19}$, critically interpret practical and concrete actions that occur within a reality, that is, they are experiences loaded with the organicity present in dynamic and complex social processes marked by the conditions of the context in which they develop, such as the facing of specific situations; actions with determined objectives; perceptions, interpretations, and intentions of the participants and their relations; and emergence of expected and unexpected results. Based on the concept of said author, one understands that it does not involve simple ordering and reporting, but includes an interpretation of the process once one discovers or exposes the logic of the experienced process, the factors that intervened on said process, how they relate among themselves, and why they related the way they did.

The task of systematizing experiences requires three basic conditions that must be developed during the process: 1) interest in learning from experience, considering it an essential learning source; 2) sensitivity to allow experiences to be expressed, which presumably involved putting inflexible thinking schemes and prejudices aside to look at the subtleties of the entire process experienced by individuals; 3 ) analytical and synthetizing skills that go beyond describing the experience in order to explore its particularities.

The systematization of the CCSAN project was based on the following main sources of information: (a) teams' assessment records of each subproject: reports, assessment instruments, and records of periodical meetings of the local teams with the central team; and (b) records (texts and photographs) of local activities: meetings for planning activities, workshops. The records were produced by the local team of each municipality, who produced reports of each activity, and by two members of the central team of the project, who acted as activity observers, recording the observations in an instrument created for this purpose.

The data in these records were organized in the following axes: mapping of the educational practices; identification of successful practices by Nongovernmental Organizations (NGO) and managers; identification of the FNS concept that guided such practices; identification of the limitations and potentialities of its operationalization according to the different actors involved; identification of the elements that, according to the actors involved, were essential for an educational practice from the FNS perspective.

The analytical reference was based on the concepts of FNE ${ }^{11}$ and FNS', and on strategic principles that guided the two concepts, such as participation, which demands active involvement of the social subjects and collective construction of the process; contextualization, which requires valuing the specificities of the contexts where the actions are developed; and intersectoriality, which requires a broad approach and an integrated perspective of food and nutrition issues.

Based on these principles, the following analytical dimensions were defined: participation; contextualization, and intersectoriality. Regarding 
participation, the analysis considered whether and how the educational practices were based on a dialogic perspective, on active learner participation, and on collective construction of knowledge, including participatory planning of actions during Contruindo capacidades em Segurança Alimentar e Nutricional. Regarding contextualization, the analysis considered whether and how the educational practices enabled contextualized learning by means of reflections about concrete daily situations lived by the participants related to the theme FNS and valuing of the local context, including food culture. Regarding intersectoriality, the analysis considered whether and how the educational practices were based on an extensive approach of the food system and whether they considered the issues related to the food and nutrition dimensions of FNS in an articulated manner.

The potentialities and limits for the development of FNS education processes at the local level, identified by the general project team and the participants of each municipal activity (government managers and technicians, social organizations, and community agents) were also emphasized as systematized in the recording and assessment instruments constructed collectively during the project.

\section{RE S U L T S}

\section{Operational design of the project}

To plan and carry out the CCSAN project, a team was created to perform two action modalities: a central team, responsible for the general coordination of the project in Brazil, Canada, and Angola, and the local teams, responsible for planning, executing, and monitoring the participating cities. The central team and local teams consisted of professors, who represented universities, and NGO professionals who promote food and nutrition security.

The project developed different modalities of educational practices organized into four subprojects. In subproject I, developed from 2004 to 2007, professors and technicians formulated and administered distance learning university courses for to improve the participants' skills; subproject II, developed from 2005 to 2006, provided in-person learning to local government and social organization managers and technicians; subproject III, developed from 2005 to 2008, trained representatives of civil society organizations involved with FNS in each municipality and societal individuals who volunteered to act as links between communities and government sectors. Subproject IV, developed from 2008 to 2009, formulated, implemented, monitored, and assessed the pilot FNS projects at the local level.

Construindo capacidades em Segurança Alimentare Nutriciona/was based on a participatory methodology ${ }^{12,20}$ as it involved all members of the central and local teams (henceforth, the term "greater team" will be used for the actions performed by the central together with the local teams) in all project stages, from planning to execution, and subproject assessment processes. Workshop activities were planned by the greater team, which promoted a rich exchange of distinct subject-specific information due to the multidisciplinarity of its members (including social scientists, economists, and health professionals, among others) and differentiated institutional vocations (universities and NGO). The participatory methodology is based on the principles of participation, dialogue, knowledge exchange, critical reflection, participatory planning, and social management ${ }^{12,20}$, and in this project its objective was to determine the local needs and mobilize social actors to create solutions for FNS-related issues.

The Construindo capacidades em Segurança Alimentar e Nutricional integrated local actors who participated in the workshops and pilot projects, some of which had been longtime social mobilization agents for FNS and active in different sectors - agriculture, health, environment, and schools, among others, which also favored 
the participation of a broad FNS approach that potentiates intersectoriality. Therefore, the processes analyzed herein are also fruit of the accumulated experience of these actors as the education actions are part of their daily work practice. This concept expresses the approach of Educação Popular, which argues that action stems from the efforts of those who live and will live off their work and that this action always has a political role 21 .

The greater team met annually, once in each city that participated in the project, allowing the participants to get acquainted with all scenarios and contexts of the activities. This practice allowed adapting the actions to the different contexts.

\section{Online courses}

Subproject I provided FNS training through four online courses: FNS Concepts and Principles; FNS Policies and Programs; FNS and Gender; and FNS Research Methods and Assessment. The courses had 401 participants who were directly involved with promoting FNS in the municipalities, including technicians from government and civil society institutions, social movements, and Non-Governmentral Organizations.

Providing the courses as the initial action of the project accomplished the objective of subsidizing/increasing FNS knowledge, not only in CCSAN participants but also in local actors from many institutions involved with FNS actions. Hence, the courses allowed the team members from each municipality and the course facilitators to participate interactively in debates and discussions, and they contributed to the consolidation and addition of essential knowledge for the development of the actions that would be carried out during the project.

Regarding the educational practices, the use of Information and Communication Technologies (ICT) in teaching potentially favors active knowledge gain and the development of specific skills because it promotes a dynamic process of critical reflections and stimulates investigative skills. Online environments promote interaction among the participants, are not limited by space and time, and widen the possibilities of education based on the participants' needs, interests, and will|22.

The assessment instruments of the online courses indicated that the students explored many resources provided by the platform (chats, classroom environment, debate forums) to share information about FNS in their local contexts. A very positive factor of interactivity established by the online courses was enabling the participants to become familiarized with the reality of different places where the project was carried out (including the respective countries of origin) and analyzed how the diverse socioeconomic, geographic, and cultural contexts influenced FNS conditioners in these distinct scenarios. The challenges were related to internet access quality in some places, and with the lack of familiarity of some participants with the interaction and learning dynamics of online environments.

The knowledge the participants gained from the courses was essential for the development of the actions performed during CCSAN as training FNS promoters was the main objective of the project and would be the focus of the subprojects that followed.

\section{The local workshops}

The greater team of the CCSAN project elected workshops as the methodology of choice for subprojects II and III because workshops promote collective knowledge construction, interaction possibilities, and knowledge exchange in the education process ${ }^{12}$.

Subproject II developed the workshop 'Local public food security policies and programs' to train managers and technicians from many governmental and civil society (NGO) institutions responsible for the planning and execution of the local FNS programs. The workshop, planned by 
the greater team, was conducted in every municipality. The local teams were responsible for making the necessary adaptations according to their specific realities.

Subproject III also developed workshops to train local actors so that they could act as links between the community and the government sectors. To achieve this purpose, the workshop themes were: Indicators of food and nutrition security; Gender and food security; Gender, food sovereignty, and food and nutrition security; Exploring identities through food security Workshop of the Indigenous Youth; Food security and rural development; Mobilization for the III National Conference on Food and Nutrition Security.

The workshops of subprojects II and III were conducted from 2005 to 2008, and the type and number of participants varied by municipality. Generally, social actors of many segments involved with the theme FNS participated, such as representatives of social movements, community leaders, indigenous leaders, elementary school teachers, employees, students, and community health agents. Women prevailed in all these segments.

Analysis of workshop participant composition in the three municipalities indicates wide and diverse participation, with the presence of institutions related to different segments, such as rural workers, indigenous ethnic groups, quilombolas (especially in Araçuaí and Juazeiro), community associations, institutions that act in the health and education areas, and organizations that act on issues related to gender inequality (in the three municipalities). Regarding the government sectors that participated in the workshops, their numbers were small when compared with those of the social organizations and restricted mainly to the departments of health, social assistance, education, and sectors associated with rural assistance. The ample and diverse composition of the workshops does not guarantee active participation in the debates because this depends on other factors, such as educational practices or issues that may inhibit the free expression of ideas. However, it signals the potential for participation and the possibility of reflections that contemplate the different factors related to FNS.

In this sense the workshop records indicate the use of techniques and resources that encourage active participation, and broad and contextualized reflections about FNS based on concrete examples, including those related to the eating practices of the participants, such as: a) use of the instrument 24-hour dietary recall and presentation of caricatures and short sentences about food, including the mysticism that involves the act of eating (Juazeiro); b) use of pictures and a set of images that make reference to daily situations to generate discussion on the understanding of the FNS concept - images of a farmer, cistern, regional food, kitchen, school, healthcare unit, crop, deforestation, agricultural burning, air pollution, water pollution (Juazeiro); c) pedagogical techniques that approach the participants' food habits and the reality of the place where they live, such as, for example, ask people to mention a fruit they relate to when they introduce themselves (Fortaleza); and d) recovery of local cultural practices to involve the participants in the discussion of subjects that, at first, may seem uninteresting (Araçuaî).

Other pedagogical techniques and resources that favor participation also stood out, such as: presentation of documents and debate; creation of work groups by using songs that each group identified as expressing themes related to FNS; dramatization of food insecurity situations; working group using many resources and factors that encourage people to participate in the debate, such as: news in newspapers and magazines that identify the violation or respect for human rights from the FNS perspective; creation of announcement boards using different resources (cutting, gluing, images) allowing the participants to discuss and explain their arguments to the other participants. To make sure the participants were encouraged to express themselves, a 
workshop in Juazeiro conducted in 2005 used smaller group projects that helped those who were reluctant to give lectures to participate. Participation in group activities allows discussion, analysis, and often, the resolution of impasse and problems. The activities developed by Coelho et $a .^{23}$ demonstrated that when people are allowed to discuss problems, they do not only exchange information, but also solve impasse and make referrals.

The experience of the farinhada is a great example of an educational practice that favored participation and contextualization of the FNS debate regarding a broad and integrated approach of food and nutrition dimensions. This experience reflects the ritual of preparing maniocbased foods in many northeastern communities and allows discussion about the progressive loss of the habit of consuming certain foods typical of the local culture and their replacement by other foods. It also allows the participants to experience the process of food production, soil selection and preparation for planting, seedling selection, planting, caring for the plant's development, harvesting the manioc, mobilizing the community to prepare the farinhada, flour arriving in homes, peeling the manioc, grinding the manioc, roasting the flour, making the food (tapioca, beiju, cake, sequilhos, almost always flavored with coconut), and tasting the food, when people carry out the rituals of thanking God for the food and festivity as element of care (Fortaleza).

Other activities also favored broad and contextualized FNS approach, emphasizing samples of local products, arts, theater, music, and food shared among the participants, carried out in the Juazeiro workshop, which integrated the discussions about culture and healthy eating with planning the meals. The meals were based as much as possible on the typical products of each region, valuing the local culture, and counted on the participation of local singers and composers to encourage the group to participate and feel more relaxed (Workshops of Juazeiro and Araçuaí, 2005).
According to the workshop records, the supply of family farm foods without pesticides, prepared by groups of solidarity economy was coherently prioritized to avoid a discourse that is not coherent or consistent with the practice (Araçuaí workshop). Thus, processed foods or foods acquired from any supplier, without welldefined criteria, were not offered. Moreover, disposable utensils were not used to avoid incoherence between discourse and practice, in agreement with Paulo Freire's ${ }^{12}$ approach, which emphasizes the importance of 'putting your money where your mouth is'. The inseparability between theory and practice presupposes that practice is also a discourse as it expresses concepts and disseminates principles; on the other hand, the discourse is a social practice because, more than just constructing representations of reality, it configures reality by producing meanings ${ }^{24}$.

One may consider that the process of constructing a FNS concept in the municipalities was contextualized because the workshop records reflect characteristics that are typical of the local contexts of daily experiences and emphasize factors that condition FNS that are specific to each context. For example, the issue of having access to water structured the conceptual debate in locations where lack of water was a more pressing problem. The constructed FNS concept covered the multiple dimensions of the concept, from the production aspects to consumption aspects, including the cultural dimension, which favors a broad and intersectoral approach. In the various workshops, the main elements of the FNS concept shared among the participants were systematized, as the following testimony illustrates: "FNS is a project that aims to improve human health and quality of life, taking into account environmental degradation, water quality, and influence of the media on food acquisition" (Workshops of Juazeiro and Araçuaí, 2005).

The pedagogical practices used by the project explored the context of the participants' experiences and combined concrete elements and "theoretical abstractions" to construct a FNS 
concept articulated with political action. It is worth noting that in all workshops the participants opted to construct a positive FNS concept based on concrete situations identified as food insecurity and experienced in each local context. Because it is an abstract notion, the process of collective construction became more viable once the problems generated by lack of FNS were identified. This proposal is based on Paulo Freire's formulations from the perspective that every individual has some knowledge, and that new knowledge is constructed from this previous knowledge ${ }^{12}$. According to this author, an essential condition to the education process is respect for another's knowledge, another's experience. Thus, sharing with the population the attempt to understand its reality, in all its complexity, is the starting point for the creation and construction of new knowledge. In addition this is in agreement with the references of Educação Popular ${ }^{25}$, such as respect for popular knowledge, promotion of citizenship and individual autonomy, and the production and experiencing of creative experiences.

During subprojects I, II, and III, FNS situation was diagnosed based on secondary data from the Instituto Brasileiro de Geografia Estatística (IBGE, Brazilian Institute of Geography and Statistics), Departamento de Informática do Sistema Único de Saúde - Ministério da Saúde (DATASUS, Department of Health System Information - Ministry of Health), and Human Development Atlas (socioeconomic, nutritional, and health indicators), which were systematized to support the debates conducted in the local workshops about the main factors that contribute to or affect the municipal food security/insecurity situation. In these debates, secondary data were used as another element of discussion, and the main issues pointed out by the participants were: the intake of processed foods; the fact that the wealth produced by food production processes does not reach the local population; unsafe foods; malnutrition; underweight; the environmental challenge; racism; gender inequalities; life conditions associated with food insecurity; and drugs/obesity. These debates favor a contextualized FNS approach by emphasizing specific conditioners in each municipality.

\section{The pilot projects}

Subproject IV formulated, carried out, monitored, and assessed pilot projects of local FNS actions. The experiences described below differed by type of action, target population, and pedagogical technique depending on the specificities of each municipality, yet they kept their common objective of qualifying the work of representatives of civil society organizations and social subjects for actions that promote FNS.

(a) Pilot project in Fortaleza: 41 community animators were trained. Community animators are women of the community that voluntarily develop actions that promote health and healthy diets to roughly 450 socially vulnerable families who benefit from three philanthropic institutions located in the city outskirts.

The initial proposal of the local team was to form community health agents to join the educational practices from the FNS perspective, but this was not possible because a new mayor assumed office in 2008. Therefore, the team looked for a new group for the action, including the selection of community animators.

The general objective of the project was to qualify the educational actions developed by community animators considering the FNS focus. Training was performed by twelve culture circles inspired by the participatory methodology and ideas of the educator Paulo Freire based on the contradictions of reality and the understanding that reality is always changing. The culture circle is a dialogic educational practice where the role of the educator is to encourage participants to exchange knowledge to create new knowledge capable of changing reality ${ }^{12,26}$.

The following themes were debated in the culture circles: understanding of social FNS 
conditioning factors; FNS development using the popular arts; development of tools to work FNS in the communities; understanding of FNS in the community; discussion of FNS indicators and their implications; study of the local FNS indicators; education on healthy eating; training in food intake focusing on groups at nutritional risk and on the most common diseases directly related to diet.

This experience enabled the creation of a portfolio, fruit of the reflections and discussions carried out by the group, called Working with FNS in the community, incorporated as a work tool by the community animators. The portfolio consists of a recording instrument, memory, planning, selfassessment, and assessment. Its main purpose is the development of reflection skills to promote progressive emancipation of the learners. The portfolio allows learners to change their reality, producing knowledge and assessing their limitations, which then allows the search for new knowledge and the transformation of practices ${ }^{27}$. Since the portfolio agreed with the project proposal, it was used as a pedagogical resource in the culture circles.

An unexpected result of the Fortaleza experience was the creation of a specialization course in FNS by a public university, consequence of a demand for qualification on the theme of FNS propelled by the project.

(b) Araçuaí pilot project: Approximately 90 people participated in the FNS education subproject, including school cooks, community health agents, teachers, employees, students' representatives, and members of the local community. Various participating institutions met to identify the municipal FNS priorities by sharing experiences, such as visiting the food outlets of the municipality.

The pilot project was based on FNSpromoting actions developed in three municipal public schools from 2007 to 2008. The actions were planned in a participatory process that involved government sectors, social organizations, and different segments that integrated the school community. The existing and necessary resources were identified to develop sustainable FNS actions in the schools and determine the possible partnerships and the challenges. The priority actions in each school included school gardens, continuous education of school cooks, and educational activities with parents and students.

(c) Juazeiro pilot project: The local experience in Juazeiro was characterized as a broad participatory planning, which included nine workshops in the municipalities of Sobradinho, Curaçá, Sento Sé, Uauá, Canudos, Casa Nova, Remanso, Pilão Arcado, and Juazeiro. Sixty-two people participated in the workshops, including community leaders, community health agents, Pastoral da Criança agents, presidents or members of community associations, rural labor unions, teachers, health professionals, and municipal managers. Many of these participants provided key information because of the knowledge they had about the life conditions of the families.

Using active methodologies that involve pedagogical group-learning techniques, the participants identified municipal and regional situations of food insecurity and their conditioners, using secondary data from multiple sources, such as the population census, which were enriched with the participants' empirical knowledge. Active methodologies consist of interactive processes of knowledge, analysis, studies, researches, and individual or group decisions to find solutions for a problem ${ }^{28}$. The development of such pedagogical practices for analyzing FNS information from the perspective of the participants' knowledge of specific municipal and regional factors may facilitate participation and contextualization.

During the workshops, the participants made a general map of the regional FNS programs and public policies, and determined those that had the greatest impact on the food and nutrition situation. We also received the results of a study done in 2006 in the arid region of São Francisco about the governance of civil society on FNS 
policy, with emphasis on the FNS Council, which was not a specific activity of the CCSAN but involved researchers of the central team of the project and enriched the experienced because it was carried out in that region.

The results of the pilot project of Juazeiro were: identification of strategies for constructing and strengthening FNS policies and programs for the Arid Territory of São Francisco; creation of an illustrated folder consisting of the ten steps to a healthy diet, made available for agents and pastoral leaders who usually educate families. One of the main challenges was the need of readapting the planning in some municipalities given the dynamics of the group and time available for the workshop. However, in the local team's assessment, this did not hinder the final result of the experience, except for Juazeiro's workshop, where only the civil society participated possibly because there were municipal elections during this time and the mayor was not reelected.

Since the pilot projects demanded the planning, implementation, and assessment of actions, they expressed potentialities and limits of the more general education process that occurred in each municipality during the other subprojects. Thus, they allowed analyzing local actor involvement, how education about FNS concepts was conducted, the articulation between actors, and other conditioners of each local context.

Chart 1 provides the systematization of some educational practices developed by the CCSAN project based on the principles that guide the FNS and FNE concepts. Some challenges that were faced during this process are described below.

\section{Challenges for carrying out educational practices}

One of the main challenges for the mobilization, involvement, and participation of government and nongovernment actors and for the continuation of educational practices developed by CCSAN were the difficulties inherent to the electoral periods and mayoral changes.

This problem occurred to a greater or lesser extent in all municipalities with different repercussions, such as: loss of actors who participated in a given stage of the process but had to leave because of changes in the team that normally characterizes management changes in civil servant jobs; staff turnover in municipal management; changes of functions and roles when actors previously affiliated with local NGO assumed functions in the city hall and received new priorities; new political party in the city hall making unviable the participation of employees or even the continuation of certain programs, actions, and projects associated with the previous management. These issues, also related to political party or ideological divergences about the courses of government actions, affected the expression of opinion of participants affiliated with governments or NGO. Sometimes they inhibited participation, depending on the composition of the workshops or even of the work groups. In other times, the project activities in some contexts favored the exposure of local conflicts, including the verbalization of demands or dissatisfactions about government actions, or even of political support and internal divergences of the institutions involved. Greater visibility of the existing conflicts and differences can occur in distinct processes and political spaces for social participation ${ }^{2-5}$.

Problems related to mayoral change mark the implementation of public policies in Brazil, and the institutionalization of SISAN is part of the legal efforts to formalize the advances achieved under favorable political conjunctures. Educational practices that establish continuous, long-term activities are less likely to bear fruit in these contexts marked by changes in government; on the other hand, specific actions are very limited because they fail to unite actors in medium- and long-term processes. 
Chart 1. Educational practices performed from 2005 to 2008 in the municipalities of Araçuaí (MG), Fortaleza (CE), and Juazeiro (BA), organized by objectives and examples of pedagogical techniques and resources according to the principles that demarcate the concepts of Food and Nutrition Security (FNS) and Food and Nutrition Education (FNE).

\begin{tabular}{|c|c|c|c|}
\hline Education practice & Objective & $\begin{array}{l}\text { Pedagogical techniques } \\
\text { and resources }\end{array}$ & $\begin{array}{c}\text { Principles of Food and Nutrition } \\
\text { Education and Security }\end{array}$ \\
\hline $\begin{array}{l}\text { Diagnosis } \\
\text { Participants: CCSAN } \\
\text { team and local actors }\end{array}$ & $\begin{array}{l}\text { 1. To map the actors } \\
\text { 2. To identify the priorities and } \\
\text { respective local actions } \\
\text { 3. To diagnose FNS situation } \\
\text { 4. To reflect about the food } \\
\text { insecurity conditions }\end{array}$ & $\begin{array}{l}\text { 1. Songs with themes related to FNS } \\
\text { (Farinhada) } \\
\text { 2. Use of the documentary "Sede de } \\
\text { comida e fome de viver" (Thirst for } \\
\text { food and hunger for living) and } \\
\text { of the video "Segurança Alimen- } \\
\text { tar na Agricultura Familiar" (Food } \\
\text { security in Family Farms) } \\
\text { 3. Puppet theater to dramatize } \\
\text { situations of food insecurity } \\
\text { 4. Identification of the regional } \\
\text { problems and strategies to fight } \\
\text { food and nutrition insecurity } \\
\text { 5. Use of images of newspapers and } \\
\text { magazines that depict the } \\
\text { violation of or respect for human } \\
\text { rights form the FNS perspective } \\
\text { 6. 24-hour recall to discuss food } \\
\text { intake }\end{array}$ & $\begin{array}{l}\text { Participation } \\
\text { 1. Collective construction of } \\
\text { knowledge and collective } \\
\text { transformation to look for } \\
\text { concrete solutions } \\
\text { 2. Educator as facilitator of the } \\
\text { process } \\
\text { 3. Combined participation in } \\
\text { the planning and } \\
\text { implementation of } \\
\text { education actions }\end{array}$ \\
\hline $\begin{array}{l}\text { Education in FNS } \\
\text { Participants: CCSAN } \\
\text { team, local actors, } \\
\text { government and NGO } \\
\text { managers and } \\
\text { technicians }\end{array}$ & $\begin{array}{l}\text { 1. To construct the concept of FNS } \\
\text { 2. To identify the factors that } \\
\text { condition FNS } \\
\text { 3. To promote FNS locally }\end{array}$ & $\begin{array}{l}\text { 1. Culture circles with themes } \\
\text { related to food and nutrition } \\
\text { 2. Technique to warm up and } \\
\text { introduce the participants, } \\
\text { mentioning specific characteristics } \\
\text { of their municipalities } \\
\text { 3. Field work consisting of visits to } \\
\text { food outlets (farmers' markets, } \\
\text { municipal markets, and } \\
\text { restaurants) } \\
\text { 4. Cooking workshop of regional } \\
\text { foods } \\
\text { 5. Distribution of food to some } \\
\text { group participants only to discuss } \\
\text { equity }\end{array}$ & $\begin{array}{l}\text { 1. Learning contextualized to } \\
\text { the local reality } \\
\text { 2. Valuation of the regional } \\
\text { food culture } \\
\text { Intersectoriality } \\
\text { 1. Full approach of the food } \\
\text { system }\end{array}$ \\
\hline
\end{tabular}

Note: NGO: Nongovernmental Organization; CCSAN: Construindo capacidades em Segurança Alimentar e Nutricional; FNS: Food and Nutrition Security.

The concept of education as a process that stems from social relationships leads to the conclusion that the construction of these relationships is essential for the course of educational actions. Even if mayoral changes have affected the educational practices carried out during the CCSAN project, its duration (six years) and the continuation of subprojects were positive factors for the construction of local partnerships.

Therefore, the articulations between actors who work more continuously at the local level, beyond government sectors, such as universities and NGO, are essential to ensure the continuation of actions in political conjunctures 
that hinder government participation, and thus to maintain the theme in the public agenda, regardless of who is in office.

Civil society organizations may be essential for political mobilization and insertion of certain themes in the government agenda, as has been the case of FNS in Brazil. In contexts where their performance is strong, it is possible to notice differences in the organization flows of local actions. The mobilization of actors for working group is, in general, a difficult process, considering the multiple activities that each sector and institution develops, and the time and energy that need to be spent in processes that involve different institutions. In this sense one of the municipalities reported having difficulties to mobilize the institutions and to get all community agents to participate in the activities developed during the pilot project. Many of these agents are volunteers in the activities, so their presence cannot be enforced.

The difficulty of mobilizing local actors and getting them to participate continuously was an issue faced by all municipalities, but to different degrees. In the case of Juazeiro, for instance, the existence of an active Regional FNS Commission (which involves representatives of FNS-related civil society organizations in 10 municipalities in the semiarid region) was a noteworthy differential as it greatly facilitated political mobilization. Initially, the commission consisted of representatives of the civil society and government, but after the electoral period, as the mayors changed, their performance also decreased. Fifty-four institutions participated in the workshop, most from the civil society (only eight government representatives) who supported or worked directly in the regional commission. Therefore, the mobilization of social organizations has been essential for the FNS theme to continue in the regional agenda.

Political mobilization activities are important for the work performed, especially by civil society organizations, because they maintain in the government agenda the themes for which they fight and ultimately, the sponsoring of the projects and financial and institutional sustainability. In educational activities, participation stems from the recognition of the importance of maintaining the network of policies created around the participating organizations, but also from the demand for continuous education that qualifies the work of these institutions. However, education activities often end up being less prioritized when more emergent or immediate institutional demands appear, which are essential for institution survival. This problem can also affect the insertion of government sectors in such processes.

Food and Nutrition Security education has been standing out as an essential strategy for the consolidation of FNS policy and SISAN throughout the country, and involves the formation of counselors from government sectors and social organizations, teachers, university students, and professionals from different fields ${ }^{29-32}$.

The Construindo capacidades em Segurança Alimentar e Nutricional experiences indicate that the development of educational FNS practices should be considered part of an institution's work to make it viable in daily professional practice. For this purpose, it is essential to understand the vocation of each institution, considering that there may or may not be a confluence of institutional vocations and interests, and that each institution has very distinct institutional dynamics and work processes.

In this sense, the integration of universities and NGO was also a challenge in locations where these institutions did not have much tradition in working together. The difficulties regard the differences between NGO and universities, especially with respect to the daily activities prioritized by the institution. Not all universities or some of their sectors have the tradition of performing community actions like some local NGO that integrated the project. Moreover, NGO often have more experience with the use of methodologies for popular education, or participatory educational methodologies. Although this varies from one university to 
another or even within universities, not all their sectors have the tradition of developing extension activities that contemplate medium- and long-term activities aimed more directly at the population.

Academic knowledge is greatly enriched when academics dialogue with managers and civil society and vice versa to incorporate their experience, a process that also characterizes the experience of consolidating FNS policy in Brazil. Civil society organizations have sometimes reached segments of the population that often are not assisted by universities or managers. The relationship with local reality and people's life dynamics is much more organized by these organizations. University extension projects are the activities that come closest to this perspective. However, they were often called extramural to reflect the limits that often situate university actions. The murals of social organizations are usually more flexible and favor the construction of "bridges" that facilitate more organic dialog with the population.

Considering the limited duration of municipal management and its reflexes on the implementation of local actions that involve governmental and nongovernmental actions, articulations between universities and civil society organizations are critical. For such, understanding its specificies in the sence of identifying spaces where the actions of these institutions converge is an important task for the consolidation of continuous education processes or at least of medium-term activities that contribute to the reconstruction of FNS values and practices.

\section{CONCLUSIONS}

Analysis of CCSAN educational practices indicates that valuable FNE and FNS presuppositions, such as participation, contextualization, and intersectoriality, were present in the project construction process.

The initial education of the local team members by online courses, and later, of the social actors involved in the municipal FNS issues by workshops favored the shared construction of FNS concepts among CCSAN members, which supported all activities performed in the different locations. The online courses provided a virtual environment that brought together people from all of Brazil and other Portuguese-speaking countries, especially Angola, and allowed broad exchange of experiences in different contexts and interaction between cultures, which would be hard to achieve in in-person processes.

The participation of the government and societal organizations involved with FNS in the municipalities in subproject creation and implementation helped the developed activities to have a meaning to the local community. Additionally, it favored opportunities for the sharing of different meanings and experiences related to food and nutrition in each context, from a participatory and contextualized perspective. The participants were diverse in terms of knowledge and vocational institutions, which included academic, governmental, societal, educational, economic, health, and agricultural institutions that deal with discussions about rurality, gender, and ethnicity, and include professionals of different educational backgrounds. This diversity, seen in both the greater team and in the participants of the local workshops, favored a broad and intersectoral FNS approach and not only a discussion restricted to food intake.

The project included broader education processes for the planning of FNS action management and educational practices identified as FNE actions. The workshops simultaneously contributed to the education of social subjects on the development of public actions and policies and consisted of FNE processes as they promoted reflections about individual and group daily practices, including reflections about the participants' eating practices. In some pilot projects, FNE actions were directed to specific segments (students' parents, students, social agents) and particular institutional contexts, such as schools. Therefore, from the CCSAN perspective, 
there was no dissociation between the educational practices that promoted the education of political FNS agents from those that provided FNE to these agents.

The discussions about the conformation of local food systems and the FNS situation of the municipal and regional populations could be problematized by reflecting about different types of data available in public information systems and dialoguing with the participants, taking advantage of their the knowledge of the local context. The different types of information approached included production, commercialization, consumption, and food culture aspects in each municipality, in addition to analyses about individual and group eating practices experienced in the context of daily life.

This dialogic perspective was potentiated by different pedagogical techniques used in the workshops that favored active participation, and broad and contextualized FNS approach. In this sense, the following stand out: the construction of a 24-hour recall; culinary workshops; visits to food outlets; dramatizations; dialogue circles; working group; the farinhada experience; and the use of pedagogical resources like songs, films, and images that express the local food culture.

The main challenges for the construction of participatory educational practices in the scope of CCSAN include government change, institutional infrastructure problems, difficulty of mobilizing the local actors and having them participate continuously, and familiarity with some pedagogical techniques (such as the online environments).

The diversity of professionals (given the distinct fields involved) and institutional vocations (such as universities and NGO) may both enrich the process of constructing shared knowledge by favoring a broad and intersectoral FNS approach and defy the participatory process by the need of handling conflicts, conceptual differences, and distinct interests.

The conflicts, divergences, and differences between those involved (politicians, and individuals with institutional or professional ties, among others) may affect the participants' willingness to express their opinions. Therefore, the CCSAN experience indicates that thinking about participatory and contextualized educational practices implies considering the concrete local FNS context, the participants' characteristics (in terms of educational, institutional ties, gender, and ethnicity, among others), and the local political and institutional context, which includes the political processes and the characteristics of the institutional political structure and management of the institutions involved.

\section{CONTRIBUTORS}

L BURLANDY participated in study conception and design, data collection and analysis, and manuscript writing and review. C ROCHA, R MALUF and MMM ÁVILA participated in study conception, data collection and analysis, and manuscript writing and review. DM FERREIRA and S PEREIRA participated in study design, data analysis, and manuscript writing and review.

\section{REFERE N CES}

1. Beghin N. A cooperação brasileira para o desenvolvimento internacional na área de segurança alimentar e nutricional: avanços e desafios. Onde estamos e para onde vamos? Brasília: Instituto de Estudos Socioeconômicos; 2014.

2. Brasil. Lei $n^{\circ}$ 11.346, de 15 de setembro de 2006. Cria o Sistema Nacional de Segurança Alimentar e Nutricional SISAN com vistas em assegurar o direito humano à alimentação adequada e dá outras providências. Diário Oficial. 18 set. 2006. [acesso 2012 jun 13]. Disponível em: http://www.planalto. gov.br/ccivil_03/_ato2004-2006/2006/Lei/L113 46.htm

3. Maluf RSJ. Segurança alimentar e nutricional. Petrópolis: Vozes; 2007.

4. Maluf RSJ, Burlandy L, Santarelli M, Schottz V, Speranza JS. Nutrition-sensitive agriculture and the promotion of food and nutrition sovereignty and security in Brazil. Ciên Saúde Colet. 2015; 20(8):2303-12. http://dx.doi.org/10.1590/1413-81 232015208.14032014 
5. Burlandy L. Segurança alimentar e nutricional: intersetorialidade e as ações de nutrição. Saude Rev. 2004, [acesso 2010 nov 18]; 6(13):09-15 http:// www.unimep.br/phpg/editora/revistaspdf/saude 13art02.pdf

6. Burlandy L, Rocha C, Maluf R. Construção da Política e da Institucionalidade da Segurança Alimentar e Nutricional no Brasil. In: Instituto de Higiene e Medicina Tropical. Segurança Alimentar e Nutricional na comunidade dos países de Língua Portuguesa: desafios e perspectivas. Rio de Janeiro: FIOCRUZ; 2013. p.77-92.

7. Instituto Brasileiro de Geografia e Estatística. Pesquisa de orçamentos familiares 2008-2009: antropometria e estado nutricional de crianças, adolescentes e adultos no Brasil. Rio de Janeiro: IBGE; 2010.

8. Instituto Brasileiro de Geografia e Estatiìstica. Pesquisa de orçamentos familiares 2008-2009: análise do consumo alimentar pessoal no Brasil. Rio de Janeiro: IBGE; 2011.

9. Boog MCF. Contribuições da educação nutricional a construção da segurança alimentar. Saúde Rev. 2004 [acesso 2010 nov 18]; 6(13):17-24. Disponível em: http://www.unimep.br/phpg/editora/revistas pdf/saude13art02.pdf

10. Valente FLS. Fome e Desnutrição: determinantes Sociais. São Paulo: Cortez; 1986.

11. Brasil. Ministério do Desenvolvimento Social e Combate à Fome. Marco de referência de educação alimentar e nutricional para as políticas públicas. Brasília: MDS; 2012 [acesso 2013 set 22]. Disponível em: http://www.ideiasnamesa.unb.br/files/ marco_EAN_visualizacao.pdf

12. Freire P. Pedagogia da autonomia: saberes necessários à prática educativa. 43ª ed. São Paulo: Paz e Terra, 2011.

13. Moreira AF, Pedrosa JG, Pontelo I. O conceito de atividade e suas possibilidades na interpretação de práticas educativas. Rev Ensaio. 2011; 13(3):13-29.

14. Masetto MT. Competência pedagógica do professor universitário. São Paulo: Summus; 2003.

15. Kruschewsky JE, Kruschewsky ME, Cardoso JP. Experiências pedagógicas de educação popular em saúde: a pedagogia tradicional versus a problematizadora. Rev Saúde Com. 2008; 4(2):160-76.

16. Festas MIF. A aprendizagem contextualizada: análise dos seus fundamentos e práticas pedagógicas. Educ Pesqui. 2015; 41(3):713-28. http://dx.doi.org/10. 1590/S1517-9702201507128518

17. Carvalho FFB. A saúde vai à escolar: a promoção da saúde em práticas pedagógicas. Physis. 2015; 25(4):1207-27. http://dx.doi.org/10.1590/S0103-7 3312015000400009
18. Oliveira SI, Oliveira KS. Novas perspectivas em educação alimentar e nutricional. Psicol USP. 2008; 19(4):495-504. http://dx.doi.org/10.1590/S010365642008000400008

19. Holliday OJ. Para sistematizar experiências. $2^{\text {a }}$ ed. Série Monitoramento e Avaliação. Brasília: Ministério do Meio Ambiente; 2006 [acesso 2012 abr 10]. Disponível em: http://www.mma.gov.br/ estruturas/168/_publicacao/168_publicacao3001 2009115508.pdf

20. Akerman M, Mendes R, Bógus CM. Avaliação participativa em promoção da saúde: reflexões teórico-metodológicas. In: Bosi ML, Mercado FJ. Avaliação qualitativa de programas de saúde. Enfoques emergentes. Petrópolis: Vozes; 2006. p.145-62.

21. Cruz PJSC, Melo Neto JF. Educação popular e nutrição social: considerações teóricas sobre um diálogo possível. Interface. 2014; 18(Supl. 2):1365-76. http://dx.doi.org/10.1590/1807-57622013.0500

22. Holanda VR, Pinheiro AKB, Pagliuca LMF. Aprendizagem na educação online: análise de conceito. Rev Bras Enferm. 2013; 66(3):406-11. http://dx.doi.org/10.1590/S0034-716720130 00300016

23. Coelho FMG, Castro TG, Campos FM, Campos MTFS, Priore SE, Franceschini SCC. Educação para promoção da saúde infantil: relato de experiência em um assentamento de reforma agrária, Vale do Rio Doce (MG). Ciên Saúde Colet. 2005; 10(3):739-47. http://dx.doi.org/10.1590/\$1413-8 1232005000300030

24. Spink MJ, Menegon VM. Práticas discursivas como estratégia de governamentalidade: a linguagem dos riscos em documentos de domínio público. In: Iniguez L, organizador. Manual de análise do discurso em ciências sociais. Petrópolis: Vozes; 2005. p.258-303.

25. Santos K, Paula EMAT. A teoria de Paulo Freire como fundamento da pedagogia social. ICE. 2014; 3(1):33-44. http://dx.doi.org/10.17564/2316-38 28.2014v3n1p33-44

26. Freire P. Pedagogia do oprimido. $17^{\mathrm{a}}$ ed. Rio de Janeiro: Paz e terra; 1987.

27. Silva RF, Francisco MA. Portfólio reflexivo: uma estratégia para a formação em medicina. Rev Bras Educ Med. 2009; 33(4):562-70.

28. Berbel NAN. As metodologias ativas e a promoção da autonomia de estudantes. Semin Ciênc Soc Hum. 2011, 32(1):25-40. http://dx.doi.org/10.54 33/1679-0359.2011v32n1p25.

29. Conselho Nacional de Segurança Alimentar e Nutricional. A construção de uma Política de Seguran- 
ça Alimentar e Nutricional: Anais do $2^{\text {a }}$ Conferência Nacional de Segurança Alimentar e Nutricional. Relatório Final. Brasília: CONSEA; 2004 [acesso 2008 ago 22]. Disponível em: www.planalto.gov.br/ consea

30. Conselho Nacional de Segurança Alimentar e Nutricional. Documento final do Encontro Nacional de Segurança Alimentar e Nutricional. Brasília: CONSEA; 2006 [acesso 2008 ago 22]. Disponível em: http://www4.planalto.gov.br/consea/publicacoes/ doc-finalencnac2006-integral_formatado.pdf/view

31. Conselho Nacional de Segurança Alimentar e Nutricional. Documento Base da III Conferência
Nacional de Segurança Alimentar e Nutricional. Brasília: CONSEA; 2007.

32. Conselho Nacional de Segurança Alimentar e Nutricional. Building up the National Policy and System for Food and Nutrition Security: The Brazilian experience. Brasília: CONSEA; 2009 [acesso 2015 ago 2]. Disponível em: https:// www.fao.org.br/download/Seguranca_Alimentar_ Ingles.pdf
Received: April 29, 2016

Final version: August 1, 2016

Approved: August 25, 2016 